\title{
The Gerrymanderers Are Coming! Legislative Redistricting Won't Affect Competition or Polarization Much, No Matter Who Does It
}

Seth E. Masket, University of Denver

Jonathan Winburn, University of Mississippi

Gerald C. Wright, Indiana University

ABSTRACT Redistricting received substantial attention in the popular media in 2011, as states redrew state legislative and congressional district boundaries. Many reformers continue to argue for a de-politicization of the redistricting process, claiming that partisan redistricting is responsible for declining electoral competition and increasing legislative polarization. Our analysis of evidence from state legislatures during the last decade suggests that the effects of partisan redistricting on competition and polarization are small, considerably more nuanced than reformers would suggest, and overwhelmed by other aspects of the political environment.

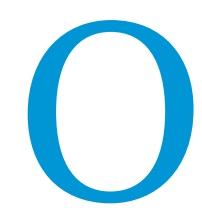

ne of the most important legacies of the 2010 election cycle will be its effect on legislative redistricting. In many states, shifts in control of the state legislature or the governor's office have led to changes in who draws the legislative maps for the next decade. How these maps are drawn could potentially swing partisan control of several state legislatures and could also affect control of the US Congress. Indeed, a few state legislators redrawing a few lines could make all the difference in determining which party controls the House of Representatives in the coming years.

Many of the arguments from political observers, however, focus less on partisan control of chambers and more on issues of polarization, competition, and basic fairness. The leader of Common

Seth E. Masket is associate professor of political science at the University of Denver. He is the author of No Middle Ground: How Informal Party Organizations Control

Nominations and Polarize Legislatures (University of Michigan Press, 2009). He can be reached at smasket@du.edu.

Jonathan Winburn is assistant professor of political science at the University of Mississippi. He is the author of The Realities of Redistricting: Following the Rules and Limiting Gerrymandering in State Legislative Redistricting (Lexington, 20o8). He can be reached at jwinburn@olemiss.edu.

Gerald C. Wright is a professor of political science at Indiana University, Bloomington. He is a co-author of Statehouse Democracy (Cambridge University Press, 1994) and numerous articles on elections and representation. He can be reached at wright1@indiana.edu.
Cause Minnesota, for example, has recently argued for redistricting reform on the grounds that the current system "moves parties farther to the left and to the right.... That polarization is really what has made our politics broken" (Brown 2011). Such arguments recur every 10 years without fail. However, as we demonstrate in this article, claims that partisan redistricting, or "gerrymandering," leads to declining competition and increasing polarization are unfounded. That redistricting can significantly affect election outcomes has been demonstrated elsewhere, and we do not investigate this phenomenon or its normative implications here. We focus on examining redistricting's effect on polarization and competitiveness, which, as it turns out, ranges from marginal to undetectable. Furthermore, as we show, the outcomes of redistricting, in terms of polarization and competitiveness, tend to be identical regardless of who is drawing the maps, which suggests that issues of fairness or inappropriateness are largely irrelevant.

\section{POPULAR BELIEFS ABOUT REDISTRICTING}

In November 2005, California's voters rejected an initiative that would have taken the task of redrawing the state's legislative districts away from the state legislature and placed it in the hands of a nonpartisan commission. (The state would adopt a similar initiative three years later.) The Los Angeles Times endorsed the initiative in strong language, explaining the problem with the districts as drawn up by the state legislature in 2001 as follows: 
The political hijacking of 2001 was so blatant that not a single one of the 153 legislative and congressional seats contested in the 2004 election changed party hands. Worse yet, scores of districts now are so solidly Republican or Democratic that only the most conservative of GOP candidates and most liberal Democrats can win them. The winner is whoever survives the party primary. This disenfranchises independents and those who would prefer to see more moderate candidates in both parties. The result is the increasing polarization of politics (Los Angeles Times staff 2005).

The Times is far from unique in its assessment of redistricting. The popular media often paint redistricting as an evil in which partisan elites and elected officials erode popular sovereignty by maliciously redrawing districts that increase party polarization and insulate incumbents. This results in voters helplessly casting votes in races that have already been decided by the placement of district lines. As Washington Post writer Juliet Eilperin (2006) opines, "It's a system in which party operatives manipulate sophisticated computer software to maximum effect, shuffling voters
4. Having a dispassionate group draw up the legislative districts would remove these problems by keeping districts competitive and limiting legislative polarization.

As plausible as this logic may be, it does not survive contact with the evidence. For one thing, in only $60 \%$ of the states are legislators actually responsible for drawing districts. In some states, legislators empower a redistricting commission to draw up the maps with no direct input from the legislature (Winburn 2008). These states have taken direct control over redistricting away from the legislature for a variety of reasons. These reasons include trying to avoid a conflict of interest of allowing the participants to determine their own boundaries, attempting to put more emphasis on traditional redistricting principles, and/or directly attempting to maximize electoral competition, as is the case in Arizona. In some cases, legislators are eager to give this power to a commission because they find the process of drawing up new districts controversial and unpleasant. Some of these commissions are designed to be nonpartisan or evenly balanced between the inter-

\section{To be sure, in some cases, legislators want to make everyone's seat a safe one. This goal is particularly useful under conditions of divided party control of the government; it keeps incumbents of both parties happy.}

across district boundaries to guarantee their candidates have the best chance of winning election every two years." Steven Hill effectively summed up popular sentiments about the 2001 Congressional redistricting cycle by saying,

$[\mathrm{M}]$ ost voters had their vote rendered nearly meaningless, almost as if it had been stolen from them.... It was more like a silent burglar in the middle of the night having his way while American voters slept. As a result of this theft, hallowed notions such as "no taxation without representation" and "one person, one vote" have been drained of their vitality, reduced to empty slogans for armchair patriots (Hill 2002, 317).

Commentators also worry about similar concerns at the state level. St. Petersburg Times columnist Martin Dyckman expressed disgust at Florida's 2000 maps, saying, "Voting is pointless more than half the time, and the people seem to know it. The sorry turnout at the polls is not passive acceptance. It is passive disgust. . You didn't choose your legislators. They chose you" (2003, D3). Even former House Speaker Newt Gingrich, who once boasted "redistricting is everything" (Nichols 1998), now worries that Democrats

get to rip off the public in the states where they control and protect their incumbents, and we get to rip off the public in the states we control and protect our incumbents, so the public gets ripped off in both circumstances.... In the long run, there's a downward spiral of isolation (quoted in Eilperin 2006).

The popular view on redistricting seems to boil down to these central ideas:

1. Legislators get to draw up their own districts.

2. They do so in a way that makes their districts safer, by limiting the number of voters of the other party. This makes their districts more partisan and less competitive.

3. With less competition and less incentive to appeal to voters of the other party, the legislature becomes more polarized. ested parties (although see McDonald 2004). Sometimes courts get involved in the process when lawsuits are filed to challenge either the legislature's or commission's final redistricting plans.

The logic outlined in the preceding text also misidentifies the varied aims of those who redraw districts. To be sure, in some cases, legislators want to make everyone's seat a safe one. This goal is particularly useful under conditions of divided party control of the government; it keeps incumbents of both parties happy. However, when a party maintains unified control of a state, it may expand the number of seats it holds in the legislature. A dominant strategy is to take safe districts and make them more marginal by moving voters who are favorable to the majority party into newly competitive districts. The result is more, not less, competitiveness, and the legislators elected from those new districts may be moderates who help depolarize the chamber.

Beyond that, in some scenarios, it is certainly possible that partisan redistricting plans can reduce competition and promote polarization (Lublin and McDonald 2006). However, as several studies have noted (Abramowitz, Alexander, and Gunning 2006; Forgette, Garner, and Winkle 2009), such effects are, at most, trivial compared to the influence of other aspects of the political environment.

\section{DATA}

\section{Competition}

We begin by looking at electoral competition in the state legislatures and breaking down the states into five different groups. The first two groups are state legislatures under unified and divided partisan control. ${ }^{1}$ The last three groups are the three different types of commissions or non-legislative methods used in the states to draw district lines: partisan, bipartisan, and judicial. ${ }^{2}$

In table 1, we examine the state legislative elections of 2002, which occurred immediately after the last round of legislative redistricting. The left-hand column of the table shows the results of a 
logit model predicting the likelihood of a contested state legislative district having a competitive election (i.e., with a margin of victory of $10 \%$ or less). We code a series of dummy variables for redistricting scheme with unified legislative redistricting as the reference category. We also account for change in control of redistricting between 1990 and 2000. The dummy variables account for change in partisan control for legislative and partisan commission states as well as whether control shifted from neutral to partisan methods or vice versa. If a state undergoes a change in partisan control, then we may see a larger effect for gerrymandering as the new party in control may undo the previous gerrymander and implement its own. Alternatively, in a move from partisan to neutral redistricting, the neutral remappers may attempt to remove any gerrymandering from the plans with the hopes of implementing a neutral plan.

Additionally, we include victory margin in 2000, the presence of an incumbent ( 1 =incumbent, $\mathrm{o}=$ open seat), district ideology (2000 presidential vote), district ideological extremism, and difference in campaign contributions between candidates as statistical controls. Finally, we cluster the observations in the model by state to account for any important differences between states.

All of the coefficients for the variables measuring who draws districts are negative, suggesting that when legislators in unified partisan control states draw their own districts, they produce more competitive districts, all else being equal. The coefficient for judicially drawn districts is negative, although not statistically significant. This suggests that if one wants to use a state's legislative redistricting procedures to make elections more competitive, let state legislators draw up their own districts.

The right-hand column in table 1 presents the results for the same variables ${ }^{3}$ predicting whether a district had an uncontested election. The results suggest that redistricting has no influence over whether a seat goes uncontested. Plans drawn by dividedgovernment legislators did not appear to create drastic incumbent protection plans that would scare away potential challengers. Also, we find no evidence that any particular type of plan compared to unified legislative plans created significantly more contested districts.

We now examine competition in state legislative elections from 2000 to 2008.4 Using the 2000 election as a baseline provides a point of comparison for any potential redistricting effects. In figures 1 and 2 we use the same measures from table 1: competitive races and uncontested seats aggregated by redistricting control. Figure 1 shows mean number of contested competitive seats by redistricting control throughout the decade. Notably, competitive rates look similar across redistricting methods, with no plan producing more than $30 \%$ competitive seats during the decade. Before redistricting, the 2000 elections showed almost identical rates of competition across the five redistricting categories. The 2002 election cycle provided slight separation as bipartisan commissions, and unified legislatures produced the highest rates of competitive races. The 2004 elections showed the most variability between methods as divided legislatures had the highest level of competitive races (28\%) compared to only $10 \%$ competitive races for partisan commission plans. However, for 2006 and 2008, competition in divided legislative plans fell to levels similar to those of 2000 and 2002.

Meanwhile, in figure 2, again no clear pattern emerges. The one exception is that bipartisan commissions consistently had the lowest rates of uncontested elections (between $28 \%$ and $35 \%$ ). Although judicial plans show a slight decrease in uncontested
Table 1

Predictors of Competitive Districts in State Legislative Elections

\begin{tabular}{|c|c|c|}
\hline & $\begin{array}{l}\text { PREDICTING } \\
\text { COMPETITIVE } \\
\text { DISTRICTS }\end{array}$ & $\begin{array}{l}\text { PREDICTING } \\
\text { UNCONTESTED } \\
\text { DISTRICTS }\end{array}$ \\
\hline Bipartisan Commission & $\begin{array}{c}-.758^{*} \\
(.317)\end{array}$ & $\begin{array}{l}-.214 \\
(.258)\end{array}$ \\
\hline Partisan Commission & $\begin{array}{r}-1.03^{* *} \\
(.337)\end{array}$ & $\begin{array}{l}-.401 \\
(.218)\end{array}$ \\
\hline Court & $\begin{array}{l}-.354 \\
(.279)\end{array}$ & $\begin{array}{l}.268 \\
(.387)\end{array}$ \\
\hline Divided Legislature & $\begin{array}{r}-1.20^{* * *} \\
(.404)\end{array}$ & $\begin{array}{l}.128 \\
(.286)\end{array}$ \\
\hline Previous Winning Margin & $\begin{array}{l}-.012^{* * *} \\
(.002)\end{array}$ & $\begin{array}{l}.019 * * * \\
(.002)\end{array}$ \\
\hline Incumbent Running & $\begin{array}{c}-.448^{* *} \\
(.168)\end{array}$ & $\begin{array}{l}.706^{* * *} \\
(.113)\end{array}$ \\
\hline District Presidential Vote & $\begin{array}{l}.0203^{*} \\
(.009)\end{array}$ & $\begin{array}{l}-.018^{* *} \\
(.007)\end{array}$ \\
\hline District Extremism & $\begin{array}{l}-.116^{* * *} \\
(.013)\end{array}$ & $\begin{array}{l}.035^{* *} \\
(.011) \\
\end{array}$ \\
\hline Difference in Campaign Contributions & $\begin{array}{c}-.280^{* *} \\
(.104)\end{array}$ & - \\
\hline $\begin{array}{l}\text { Change in Party Control of } \\
\text { Redistricting }\end{array}$ & $\begin{array}{l}-.324 \\
(.247)\end{array}$ & $\begin{array}{r}.029 \\
(.270)\end{array}$ \\
\hline $\begin{array}{l}\text { Partisan } \rightarrow \text { Neutral Redistricting } \\
\text { Control }\end{array}$ & $\begin{array}{c}.641 \\
(.349)\end{array}$ & $\begin{array}{l}-.007 \\
(.407)\end{array}$ \\
\hline $\begin{array}{l}\text { Neutral } \rightarrow \text { Partisan Redistricting } \\
\text { Control }\end{array}$ & $\begin{array}{r}-1.05^{* *} \\
(.355)\end{array}$ & $\begin{array}{l}-.403 \\
(.398)\end{array}$ \\
\hline Constant & $\begin{array}{c}.523 \\
(.489)\end{array}$ & $\begin{array}{c}-1.48^{* * *} \\
(.294)\end{array}$ \\
\hline $\mathrm{N}$ & 3,492 & 5,602 \\
\hline R-squared & 0.16 & 0.12 \\
\hline
\end{tabular}

Dependent variable in the first column measures whether a district was competitive. We define competitive as a winning margin of $10 \%$ or less. Dependent variable in the second column measures whether a district saw an uncontested race or not. Cell entries are logit coefficients. Standard errors are in parentheses. Asterisks indicate statistical significance $\left({ }^{*} p \leq .05,{ }^{* *} p \leq .01,{ }^{* * *} p \leq .001\right)$. Logit regression includes robust standard errors clustered by state.

seats throughout the decade, these plans did not produce substantively different results than the partisan methods.

One final trend (or non-trend) from figures 1 and 2 is worth noting. There appears to be no substantive change in these two measures of competition resulting from the post-200o redistricting cycle. Even when controlling for who draws the maps and their varied strategic interests, we do not find any support for the argument that gerrymandering is decreasing electoral competition.

\section{Polarization}

The evidence presented earlier suggests little effect on electoral safety by redistricting. Are the critics of partisan redistricting correct, however, that redistricting is contributing to the polarization of American politics? We address this question by looking again to evidence from the state legislatures. 
Figure 1

\section{Percent of Districts that are Competitive, by Redistricting Method, 2000-2008}
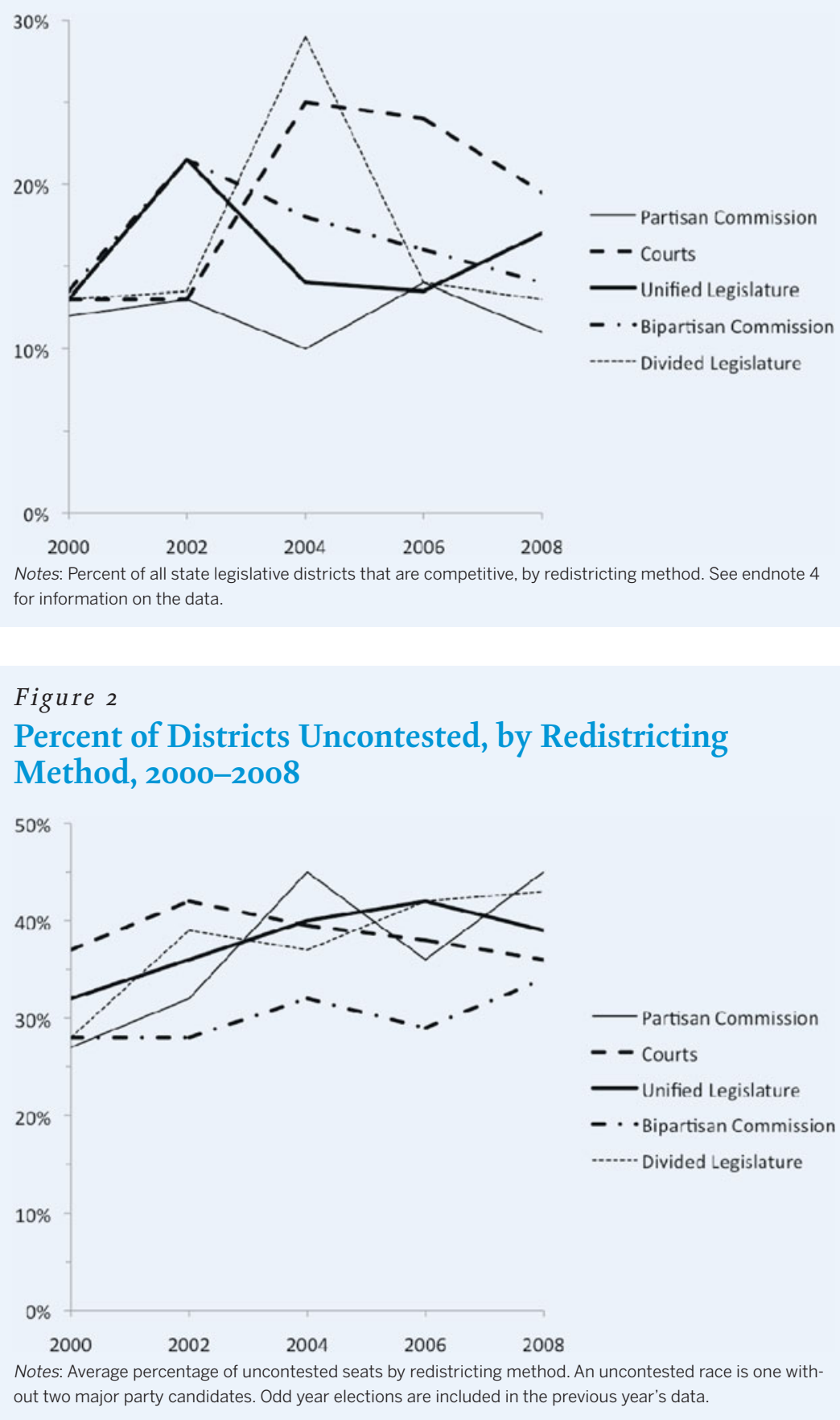

As we see in table 2, over this brief time, most changes in legislative polarization have been small and not in the expected direction. Only those states using neutral redistricting schemes (bipartisan commissions or courts) saw increases in the correlation between ideal points and party; states using other methods saw modest declines in this measure of polarization. The difference in partisans' NOMINATE scores, meanwhile, increased by .075 in those states using bipartisan commissions and .086 under court drawn plans. Scores declined, however, in the states using partisan methods. The trend is consistent across both measures of legislative polarization. Judging by these state legislatures, partisan redistricting schemes are, if anything, associated with declining legislative polarization. It is possible that this is evidence of redistricting officials who are trying to increase the seats held by the majority party, which creates more moderate districts in the process. These are possibly just spurious relationships. There is no support for the idea, however, that partisan gerrymandering causes an increase in legislative polarization.

An alternative approach is to examine the effect of redistricting methods over several decades. California provides a convenient test case for longitudinal analysis because the state has experienced several types of redistricting in recent decades. Although traditionally a legislative-redistricting state, the congressional and state legislative districts were redrawn by judges after the 1990 census.

Here, we use the presidential vote to gauge change in the underlying partisanship of the state's Assembly districts. Highly competitive districts result when the winning party's margin is relatively slight over the opposition. Our overall measure is the difference in presidential vote (2000) between districts won by Democrats and those won by Republicans; the higher the number, the safer the districts. Figure 3 shows the results for the past three decades. The gray bars immediately after 1980, 1990, and 2000 indicate redistricting periods. Fitting with conventional wisdom, this graph shows electoral safety increasing after the legislative redistrictings of 1980 and 2000, while districts became more competitive after the judicial redistricting of 1990. Yet the increased electoral safety that occurs between

In table 2, we use evidence from the Representation in America's Legislatures project to calculate legislative polarization in two different legislative sessions: 1999-2000 and 2003-2004. Eighty state legislatures were available for this comparison. We use two different measures of legislative polarization in table 2:

1. The correlation of W-NOMINATE scores (Poole and Rosenthal 1997) and party identification.

2. The distance between the average Republican's W-NOMINATE score and the average Democrat's W-NOMINATE score. redistrictings is greater than that which occurs during them. For example, the difference in presidential voting went from .19 to .24 between 1992 and 2000, when no redrawing had occurred. The next legislative redrawing only raised that difference from .24 to .26.

\section{DISCUSSION AND CONCLUSION}

Our findings are consistent with other research that shows that redistricting has extremely modest effects on the modern trends of increasing polarization and declining competition. These effects, where they exist, are also not as straightforward as critics of 
Table 2

\section{Changes in State Legislative Polarization between 1999 and 2004}

\begin{tabular}{lcc} 
REDISTRICTING SCHEME & $\begin{array}{c}\text { INCREASE IN } \\
\text { NOMINATE/PID } \\
\text { CORRELATION }\end{array}$ & $\begin{array}{c}\text { INCREASE IN } \\
\text { INTER-PARTISAN } \\
\text { DIFFERENCE IN } \\
\text { NOMINATE SCORES }\end{array}$ \\
\hline Divided Legislature & -.037 & -.021 \\
\hline Unified Legislature & -.020 & -.039 \\
\hline Partisan Commission & -.291 & -.377 \\
\hline Nonpartisan Commission & .025 & .075 \\
\hline Courts & .048 & .086 \\
\hline All Partisan & -.082 & -.099 \\
\hline All Nonpartisan & .036 & .081 \\
\hline
\end{tabular}

Figure 3

California Assembly District Polarization, 1976-2004

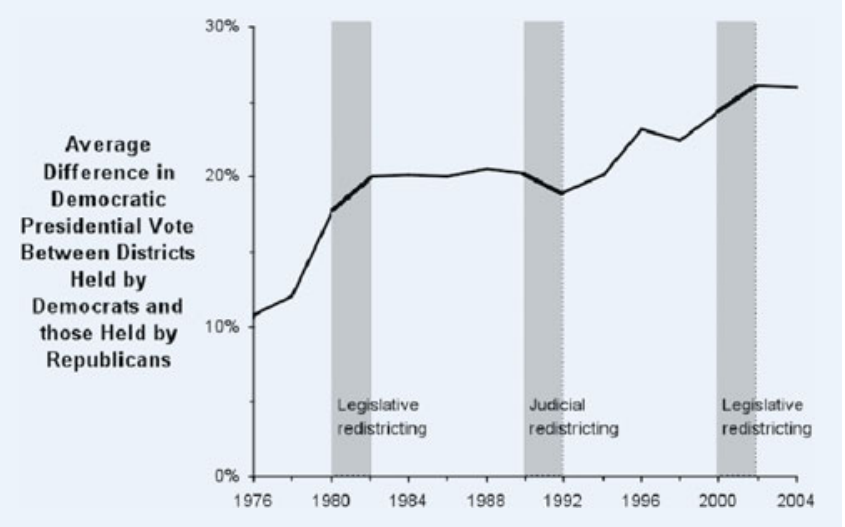

partisan redistricting suggests. To be sure, in the first election after redistricting, when legislatures in states with divided partisan control redraw districts, they do so in a way that reduces political competition; they protect incumbents. However, when legislators under unified partisan control draw the maps, 5 their results often actually increase competition, at least initially. Furthermore, the bipartisan "neutral" commissions that some states have appointed to redraw their districts have seen less-competitive elections immediately following redistricting. However, these trends do not appear to hold with subsequent elections; we do not find evidence of clear long-term trends in levels of competition. We also found that redistricting does not appear to influence candidates' decisions to run; there were no significant differences of redistricting control on contestation.

Our findings on polarization run counter to the predictions of partisan redistricting's critics. Although our data were limited to a narrow slice of recent political history, the states with nonpartisan redistricting methods saw their legislatures become more polarized, while those states with partisan methods saw slight de-polarization, on average.

The lesson for would-be reformers of redistricting is that the process can be used for multiple purposes and with varying out- comes depending on the motives of those who manage it. If reformers seek to produce more competitive elections, taking redistricting out of the hands of a unified legislature and giving it to a bipartisan or judicial commission could result in less competitive elections. Overall the effect of redistricting on electoral competition and legislative polarization, however, seems to pale in comparison to those of other aspects of the political world.

\section{NOTES}

1. In this categorization, we account for the party of the governor and their veto status. Therefore, unified states are those with one-party control of both legislative chambers and the governor's office where the governor has veto authority.

2. We code Iowa as a bipartisan commission while recognizing its unique structure of using its nonpartisan staff to construct the lines while still giving legislators a chance to vote on the plans. Given the purpose of this system, we argue it best fits in the bipartisan commission coding.

3. We cannot use campaign spending as a predictor, since unchallenged candidates generally do not spend very much money, and candidates who are not running obviously spend none.

4. The data comes from Carsey et al.'s State Legislative Election Returns Data, 1967-2003, and election returns collected from http://www.followthemoney.org. Additionally, we augment the collection with the Forgette, Garner, and Winkle (2009) data. We drop Nebraska since the legislature is nonpartisan. We include multi-member districts using the method put forth by Berry, Berkman, and Schneiderman (2000). Finally, all odd-year elections are included in the previous year's results (i.e., 2009 with 2008).

5. Note that certain states (i.e., Indiana, New York) have a tradition of allowing each chamber to control its process with little interference from the other chamber regardless of partisan majority. In this situation, the strategic situation may look more like a unified situation. However, the remappers must still respect the divided nature of the situation as the other chamber majority could step in at any time to limit the partisan nature of a plan (see Winburn 2008 for a discussion of this situation in Kentucky in 2000). Such arguments about the coding of chambers, however, do not affect our larger conclusions: redistricting in general, partisan or commission or even by the courts does not systematically lead to less competition.

\section{REF ER E N C ES}

Abramowitz, Alan I., Brad Alexander, and Matthew Gunning. 2006. "Incumbency, Redistricting, and the Decline of Competition in U.S. House Elections." Journal of Politics 68: 75-88.

Berry, William, Michael Berkman, and Stuart Schneiderman. 20oo. "Legislative Professionalism and Incumbent Reelection: The Development of Institutional Boundaries." American Political Science Review 94: 859-74.

Brown, Alleen. 2011. "Looking to the People to Fix a Broken Redistricting System." Twin Cities Daily Planet, August 23.

Dyckman, Martin. 2003. "In Florida, We Don't Choose Our Legislators, They Choose Us." St. Petersburg Times. October 12, D3.

Eilperin, Juliet. 2006. “The Gerrymander that Ate America." Slate Magazine, April 17, http://www.slate.com/id/2140054/.

Forgette, Richard, Andrew Garner, and John Winkle. 2009. "Do Redistricting Principles and Practices Affect U.S. State Legislative Electoral Competition?" State Politics and Policy Quarterly 9: 151-75.

Hill, Steven. 2002. "Behind Closed Doors: The Recurring Plague of Redistricting and the Politics of Geography." National Civic Review 91: 317-30.

Los Angeles Times staff, 2005. "Times Endorsement: A New Political Landscape." Los Angeles Times, October 23, $\mathrm{M}_{4}$

Lublin, David, and Michael P. McDonald. 2006. "Is It Time to Draw the Line? The Impact of Redistricting on Competition in State House Elections," Election Law Journal 5: 144-57.

McDonald, Michael P. 2004. "A Comparative Analysis of Redistricting Institutions in the United States, 2001-02." State Politics and Policy Quarterly 4: 371-95.

Nichols, John. 1998. "Power to Redistrict Is the True November Prize." The Nation 267: November 2.

Poole, Keith T., and Howard Rosenthal. 1997. Congress: A Political-Economic History of Roll Call Voting. New York: Oxford University Press.

Winburn, Jonathan. 2008. The Realities of Redistricting: Following the Rules and Limiting Gerrymandering in State Legislative Redistricting. Lanham, MD: Lexington Books. 